\title{
The Influence of Work Motivation, Career Development, and Work Environment on Organizational Citizenship Behavior (A Case of Mold Manufacturing Unit of PT. Bumimulia Indah Lestari, The Branch of Cikarang)
}

\author{
Retno Purwani Setyaningrum ${ }^{1}$, Avinash Pawar ${ }^{2}$, Anggi Pujiono ${ }^{3}$ \\ Pelita Bangsa University Majoring Management Economic ${ }^{1,3}$, University of Pune ${ }^{2}$ \\ retno.purwani.setyaningrum@pelitabangsa.ac.id ${ }^{1}$, avinashpawar@outlook.com², \\ pujionoanggi@gmail.com ${ }^{3}$
}

\begin{abstract}
Organizational Citizenship Behavior (OCB) is a positive behavior that will have a good impact on the organization as a whole. Hence,the company needs to develop OCB behavior towards all employees of the company. This research is motivated by the decline in employee organizational behavior towards the company. The problem is whether work motivation, career development, and work environment can influence organizational citizenship behavior among the employees in the Department of Mold Manufacturing of PT. Bumimulia Indah Lestari.This study used a questionnaire method that involved as many as 47 people from all employees in the Department of Mold Manufacturing, which totaled 47 employees. Testing in this study used a saturated sample technique, where the results of 47 respondents were processed using regression analysis and assisted by the SPSS version 22 program. The findings in this study prove that all hypothesized relationships were proven to be supported. The results of the study prove that there was a significant influence between Work Motivations on OCB [1]. There was a positive and significant influence between Career Development on OCB [2]. There was a positive and significant influence between the Work Environment on OCB [3]
\end{abstract}

Keywords: Work Motivation, Career Development, Work Environment, and Organizational Citizenship Behavior

\section{Introduction}

In the present time, the role of humans in determining organizational success cannot be ignored. Organizational citizenship behavior is a very important aspect of work. An organization will succeed if employees not only carry out their main tasks, but also want to do extra tasks such as willing to work together, help each other, provide suggestions, actively participate, provide extra service to customers, and want to use their work time effectively. These behaviors represent more added values that become a form of positive, constructive and meaningful social behavior that helps in organizations.

Before employees can perform such work behaviors, there will be factors causing them to do such behavior, which is mainly caused by a high level of work motivation, good career paths and work environment factors that allow good cooperation in carrying out tasks given by the company leader to happen. PT. Bumimulia Indah Lestari is engaged in the plastic packaging industry producing such as oil bottles, perfume bottles, poison bottles, Tupperware, and many others. Human resourcesare one thing that supports the smooth production activities 
at PT. Bumimulia Indah Lestari. Therefore, efforts to develop the quality of human resources are needed. The problem that occurs at this time is the decline in the level of loyalty or behavior of employees towards the organization that can affect the accomplishment results of the targets set by the company.

As the demand for production is increasing, more contribution from the employee behavior is needed than usual so that the company can meet certain production demand. Due to the low level of employee concern for the organization, various ways to improve employee welfare for the organization are needed.

Table 1. Employee Attendance

\begin{tabular}{lccccccc}
\hline $\begin{array}{c}\text { Month / } \\
\text { Information }\end{array}$ & L & LA & S & P & SP & AL & A \\
\hline January 2020 & 125 & 6 & 30 & 0 & 3 & 3 & 1 \\
February 2020 & 144 & 2 & 12 & 0 & 6 & 42 & 2 \\
March 2020 & 109 & 2 & 14 & 0 & 0 & 29 & 6 \\
\hline
\end{tabular}

Information:

L: Late

LA: Leave Early

S: Sick

P: Permission to not Come to Work (Salary Deduction)

SP: Special Permission

AL: Annual Leave / Personal Leave

A: Absent (Employees are Absent without Explanation)

From the phenomena that occurred in the Mold Manufacturing Department of PT. Bumimulia Indah Lestari, one way to overcome the decline in employee loyalty to the organization following the research of [4], is to grow OCB on each of the company's employees. Growing OCB requires the implementation of a certain method because OCB is not easy for every employee to have. Furthermore, [6] states that there is an influence of motivation on organizational citizenship behavior. This opinion is corroborated by [7] which states that there is a significant influence between work motivations on organizational citizenship behavior. [2] Also argues that work motivation has a significant influence on organizational citizenship behavior in the secretariat of Regional House of Representative of Bandung Regency and this is strengthened by the research of [7] which states that work motivation, clarity of purpose, and agreement factors can predict the highest impact on organizational citizenship behavior. However, [8] shows a significant negative relationship between instrumental and self-concept of external motivation and organizational citizenship behavior and this is an interesting gap for further investigation.

Employee career development is needed in human resource management to improve the quality of work of employees and companies. Career growth and success for individuals can help employers create and or strengthen career path systems and improve organizational performance by supporting the advancement of their employees [9]. Moreover, [10] states that the relationship between organizational citizenship behavior (OCB) and task performance and individual career outcomes is positive. This opinion is supported by [11], which states that the reward system supports career development strategies and organizations enhance OCB. 
A conducive work environment can provide a sense of security and allow employees to work optimally. If an employee can enjoy the work environment where he works, the employee will feel comfortable in his workplace and be able to do his activities so that his working time can be used effectively. Human life is inseparable from various conditions in the surrounding environment. There is a very close relationship between humans and their environment. In this case, humans will always try to adapt to various conditions in the surrounding environment. Likewise, when doing work, every employee will interact with various conditions in the work environment. A work environment in a company is very important for management to consider. Although the work environment does not carry out a production process in the company, the work environment has a direct influence on the employees who carry out the production process. Subsequently, [12] states that the work environment has a positive and significant effect on organizational citizenship behavior. The statement is also supported by [13] which states that the work environment has a significant effect on organizational citizenship behavior. Furthermore, [14] states that the work environment has a significant effect on organizational citizenship behavior; however, the research results of [15] about OCB highlight the dark side of citizenship behavior. In this condition, OCB does more harm than good.

\section{Literature Review}

\subsection{Organizational Citizenship Behavior}

According to [16], Organizational Citizenship Behavior is an individual contribution that exceeds the demands of roles in the workplace. Organizational citizenship behavior involves several behaviors including helping others, volunteering for extra tasks, and complying with rules and procedures at work. Organizational Citizenship Behavior is a free individual behavior, which is not directly or explicitly recognized by the reward system and in promoting the effective functioning of the organization. Additionally, [4] explains it in other words that OCB is employee behavior that exceeds the required role, which is not directly or explicitly recognized by the formal reward system and is a behavioral choice that is not the part of an employee's work obligations but supports the functioning of the organization effectively. As [4] states that there are five indicators of OCB.

a) Altruism: An employee's behavior in helping his coworkers who are experiencing difficulties regarding tasks in the organization and other people's problems.

b) Conscientiousness: A behavior that is shown by trying to exceed what is expected by the company. This is a voluntary behavior that is not an obligation or duty of the employee.

c) Sportsmanship: A behavior that tolerates what is less than the ideal conditions in an organization without raising objections. Someone who has a high level of sportsmanship will promote a positive climate among employees. Besides, employees will be more polite to cooperate with others so that it will create a more pleasant work environment.

d) Courtesy: A behavior that maintains good relations with coworkers to avoid interpersonal problems. Someone who has this dimension is someone who respects and cares for others.

e) Civic Virtue: A behavior that indicates responsibility for the life of the organization (following changes in the organization, taking initiatives to recommend how the 
organization's operations or procedures can be improved, and protecting resources owned by the organization).

\subsection{Work Motivation}

Motivation, according to [17], is a factor that drives a person to do certain activities. Therefore, motivation is often interpreted as a factor driving a person's behavior. Every activity carried out by someone must have a factor that drives this activity. Thus the motivating factor for someone to carry out a certain activity, in general, is the person's needs and desires [17]. If someone needs and wants something, he is compelled to do certain activities to get what he needs. A person's needs and desires are different from the needs and desires of others. The difference in the needs and desires of one person to another occurs because of the mental processes that have taken place in a person.

Motivation, according to [18], is a drive from within individuals to carry out certain activities in achieving goals. By providing the right motivation, employees will be encouraged to do everything possible in carrying out their duties, and they believe that with the success of the organization to achieve its goals and objectives, then their interests will be maintained as well. According to [19], the indicators of work motivation are such as:

a) The direction of behavior: Having a good relationship with coworkers, obeying work rules set by the company, never skipping work, or not attending without notice, being on time at work every day.

b) Level of effort: It has the initiative to improve the work results that are not yet good, increasing the accuracy in working to reduce errors, and concentrating on working on getting satisfactory work results that have been targeted.

c) Level of persistence:Trying to complete work according to organizational standards, trying not to make mistakes in work, not be easy to give up when getting a reprimand from the leader but being more motivated instead, and still managing to come to work as usual when the weather is bad.

\subsection{Career Development}

According to [17], career development is personal improvements made to achieve a career plan. Many people fail to manage their careers because they do not pay attention to the basic concepts of career planning. They do not realize that career goals can spur their careers and produce greater success. Although an understanding of these concepts does not provide a guarantee, if the concepts lead to career goals setting, career planning is more likely to be accomplished. According to [20], deliberate and conscious actions must be directed. Also, attitudes, behaviors, competencies, and knowledge need to be directed to be relevant to organizational goals. In this process, the organization acts as the heartbeat of career development. Career development is efforts or ways carried out by an employee and or by human resource managers as a means of developing the potential of employees to be able to occupy higher positions in achieving shared goals. [21] Career development involves a variety of functions and roles in life, and this includes education, training, paid and unpaid work, family, voluntary work, recreational activities and many more. [22] Career development is a program of development and organizational commitment that has a partial effect on employee job satisfaction. According to [2], the indicators of career development are as the following: 


\section{a) Education and training}

Education and training have a very important role in assisting employees to be more creative in achieving company goals. Education and training is an ongoing process, not a momentary process, given the rapid development of technology and knowledge as it is today. Education is an effort to develop human resources, especially developing intellectual abilities and personalities. This is because many organizations and employees find it difficult to develop careers effectively and in full of strategy [23]. Moreover, [24] states that the practical effect of training and development is on the performance in the workplace that has a positive impact on employee performance and the improvement of their skills and work efficiency. Furthermore, [25] states that during organizational development, employee training plays an important role in improving performance as well as increasing productivity.

\section{b) Job Promotion}

Job promotion is the transfer of employees from a position to a higher one with responsibilities, facilities, salaries, and career opportunities that are better than the previous position.

\section{c) Tour of duty}

The tour of duty is the transfer of work of an employee in an organization that has the same level from the previous position. This aims to place an employee in a more appropriate position and also to develop the potential possessed by an employee.

\subsection{Work Environment}

Work environment, according to [26], is what exists in the worker's environment that can influence the process of carrying out tasks such as temperature, humidity, ventilation, lighting noise, cleanliness of the workplace, and the adequacy of work equipment. The work environment can be interpreted as the whole tools faced by employees, the environment in which a person works, work methods, and the effects of work both to individuals and to groups. The work environment is anything that exists around workers or employees that can affect employee job satisfaction in carrying out tasks so that maximum work results can be obtained. In this work environment, there are work facilities that support employees in completing tasks assigned to them and that improve employee work within the company. According to [12], the work environment is all tools and equipment employees deal with in their surrounding environment where they work, the work method, and the work setting for both individuals and as groups. The indicators of the work environment, according to [13] are as follow:

\section{a) Physical Work Environment}

The physical environment is the environment around the workers. Conditions in the work environment can affect employee job satisfaction, and this includes lighting, air temperature, noise, use of color, required space, and safety of workers.

\section{b) Non-Physical Work Environment}


The non-physical work environment is all conditions that occur and are related to work relationships, both relationships with superiors and relationships with colleagues, or relationships with subordinates.

a) Relationships with colleagues.

b) Relationships of superiors with subordinates.

c) Relationships of subordinates with superiors.

However, [27] states that a lack of attention to the work environment can cause a problem because it affects the health of workers and the performance of the organization. Based on the synthesis of the literature, the researchers have formulated the following Research Hypothesis

a) Hypothesis $1(\mathrm{H} 1)$ : The Influence of Work Motivation on Organizational Citizenship Behavior

b) Hypothesis $2(\mathrm{H} 2)$ : The Influence of Career Development on Organizational Citizenship Behavior

c) Hypothesis 3 (H3): The Influence of Work Environment on Organizational Citizenship Behavior

\section{Conceptual Framework of the Study}

In the study of the influence of work motivation, career development, and work environment on organizational citizenship behavior, the method used was the quantitative research method. According to [28], quantitative research can be interpreted as a research method based on the philosophy of positivism, which is used to examine specific populations or samples, which collect data using research instruments, whose analysis of data is quantitative or statistical, and whose aim is to describe and test hypotheses which have been set. Based on the relationship framework of motivation, career development, work environment on organizational citizenship behavior, the conceptual framework can be arranged as shown below (Figure 1).

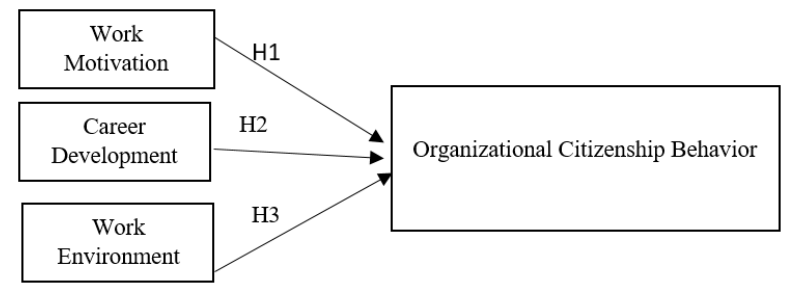

Fig.1. Framework of Study

\section{Research Methods of the Study}

In the study of the influence of work motivation, career development, and work environment on organizational citizenship behavior, the method used was the quantitative research method. According to [28], quantitative research can be interpreted as a research 
method based on the philosophy of positivism, which is used to examine specific populations or samples, which collect data using research instruments, whose analysis of data is quantitative or statistical, and whose aim is to describe and test hypotheses which have been set. This research was conducted in the Mold Manufacturing Department of PT. Bumimulia Indah Lestari at Jl. Jababeka XVI Kav. V No.65A, Industrial Area of Jababeka 1 Cikarang. The population is the whole element that will be used as a generalization area [28]. The population element is the whole object to be measured, which is the unit being studied. The population of this research was all of the employees in the Mold Manufacturing Department of PT. Bumimulia Indah Lestari Cikarang, totaling 47 employees, with the following details:

$\begin{array}{ll}\text { Manager } & : 1 \text { person } \\ \text { Asst. Manager } & : 1 \text { person } \\ \text { Supervisor } & : 3 \text { people } \\ \text { Admin Staff: 1 person } \\ \text { Operator } & : 39 \text { people } \\ \text { Total } & : 47 \text { people }\end{array}$

PT. Bumimulia Indah Lestari Plant Cikarang had 47 employees, and this study involved a total of 47 employees. The sample is part of the number and characteristics possessed by the population [28]. The analysis of this study used non-probability sampling which is a sampling technique that does not provide opportunities or chances at all to each element or member of the population to be selected as a sample [28]. The sampling technique used was saturated sampling. It is a sample that will not increase the representation when the number of sample is added so that it will not affect the value of information that has been obtained [28]. The sample in this study were 47 employees.

\section{Results and Discussions}

The analysis and results of the study are derived using the tool of SPSS as below.

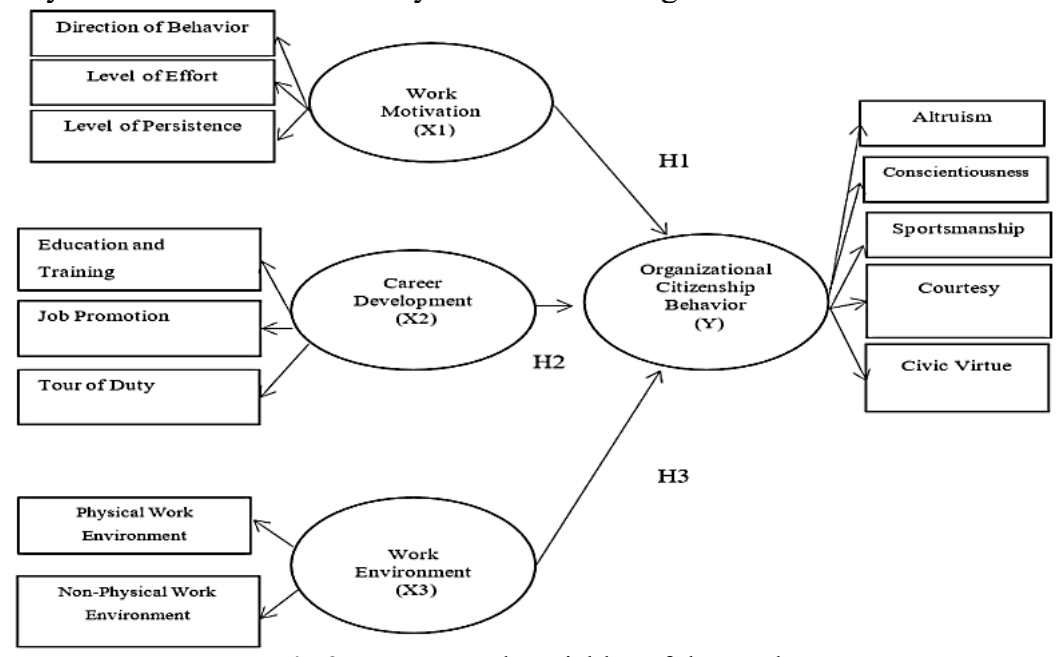

Fig.2. Groups and Variables of the Study 
Table 3. Result of Validity Test

\begin{tabular}{lcc}
\hline \multicolumn{1}{c}{ Variable } & $\begin{array}{c}\mathbf{N} \\
\text { Item }\end{array}$ & $\begin{array}{c}\mathbf{R} \\
\text { Calculate }\end{array}$ \\
\hline Work Motivation & 6 & $>0.2876$ \\
Career Development & 6 & $>0.2876$ \\
Work Environment & 6 & $>0.2876$ \\
Organizational Citizenship Behavior & 10 & $>0.2876$ \\
\hline
\end{tabular}

Table 4. Result of Reliability Test

\begin{tabular}{lcc}
\hline \multicolumn{1}{c}{ Variable } & $\begin{array}{c}\text { N } \\
\text { Item }\end{array}$ & $\begin{array}{c}\text { Cronbach } \\
\text { Alpha Value }\end{array}$ \\
\hline Work Motivation & 6 & 0.856 \\
Career Development & 6 & 0.744 \\
Work Environment & 6 & 0.777 \\
Organizational Citizenship Behavior & 10 & 0.797 \\
\hline
\end{tabular}

Table 5. Result of Hypothesis Test

\begin{tabular}{|c|c|c|c|c|}
\hline Hypothesis & Variable & T Value & SIG & Result \\
\hline H1 & $\begin{array}{l}\text { Work Motivation influences } \\
\text { Organizational Citizenship } \\
\text { Behavior }\end{array}$ & -2.531 & 0.015 & Accepted \\
\hline $\mathrm{H} 2$ & $\begin{array}{l}\text { Career Development } \\
\text { influences Organizational } \\
\text { Citizenship Behavior }\end{array}$ & 4.379 & 0.000 & Accepted \\
\hline H3 & $\begin{array}{l}\text { Work Environment influences } \\
\text { Organizational Citizenship } \\
\text { Behavior }\end{array}$ & 2.182 & 0.035 & Accepted \\
\hline
\end{tabular}

It is realised that the validity and reliability of the study are confirmed. Moreover, the hypothesis is tested and found significant for acceptance. This emphasises that the Work Motivation, Career Development, and Work Environment influences Organizational Citizenship Behavior. The data analysis used was the normality, correlation, and regression tests and hypothesis testing of each variable, which can be concluded as follows:

\subsection{The Discussion on the Role of Developing Work Motivation Will Influence Organizational Citizenship Behavior}

Based on all tests on the influence of work motivation on organizational citizenship behavior that was carried out above, the test results on the t-test yielded a $t$ calculate of -2.531 with a significance level of 0.015 , which means $t$ calculate $>t$ table and sig $<0.05$. This means that the hypothesis proposed by the researchers was accepted, meaning that there was a significant influence between the variable of work motivation on organizational citizenship behavior in the Mold Manufacturing Department of PT. Bumimulia Indah Lestari. The value of effective contribution (SE) obtained was $6.6 \%$. This shows that there was a direct influence between the variable work motivations (X1) on the variable organizational citizenship behavior (Y). The results of this study are consistent with the previous research conducted by 
[1] which states that there was an influence of motivation on organizational citizenship behavior. This opinion is strengthened by [6] which states that there was a significant influence between work motivations on organizational citizenship behavior. The work of [6] also argues that work motivation had a significant influence on organizational citizenship behavior in the secretariat of the Regional House of Representative of Bandung Regency. Thus it can be concluded that work motivation had a positive effect and had an important influence on improving organizational citizenship behavior of employees in the Mold Manufacturing Department of PT. Bumimulia Indah Lestari.

\subsection{The discussion on the Role of Appropriate Career Development Will Influence Organizational Citizenship Behavior}

Based on all tests on the influence of career development on organizational citizenship behavior that was carried out above, the test results on the t-test yielded a t calculate of 4.379 with a significance level of 0.000 which means $t$ calculate $>t$ table and sig $<0.05$. This means that the hypothesis proposed by the researchers was accepted, meaning that there was a positive and significant influence between the career development variable on organizational citizenship behavior in the Mold Manufacturing Department of PT. Bumimulia Indah Lestari. The value of Effective Contribution (SE) obtained was $28.7 \%$. This shows the direct influence between the variable of career development (X2) on the organizational citizenship behavior (Y) variable. The results of this study are consistent with previous research conducted by [8] stating that career development had a significant effect on organizational citizenship behavior. This opinion was supported by [9] who argues that career development had a significant effect on organizational citizenship behavior. This opinion is also reinforced by [12] which states that career development had a significant effect on organizational citizenship behavior. So it can be concluded that career development had a positive effect and had an important influence on improving organizational citizenship behavior of employees in the Mold Manufacturing Department of PT. Bumimulia Indah Lestari.

\subsection{The discussion on a Good Work Environment Will Affects Organizational Citizenship Behavior}

Based on all tests about the influence of the work environment on organizational citizenship behavior that has was out above, the test results on the t-test yielded $t$ calculate of 2.182 with a significance level of 0.035 which means $t$ calculate $>t$ table and $\operatorname{sig}<0.05$. This means that the hypothesis proposed by the researchers was accepted, meaning that there was a positive and significant influence between the variable of work environment on organizational citizenship behavior in the Mold Manufacturing Department of PT. Bumimulia Indah Lestari. The value of Effective Contribution (SE) obtained was $8.1 \%$. This shows that there was a direct influence between the variable of the work environment (X3) on the organizational citizenship behavior $(\mathrm{Y})$ variable. The results of this study are following the previous study conducted by [3] stating that the work environment had a positive and significant effect on organizational citizenship behavior. The statement was also supported by [13] which states that the work environment had a significant effect on organizational citizenship behavior. Moreover, [14] states that the work environment had a significant effect on organizational citizenship behavior. So it can be concluded that the work environment had a positive effect 
and had an important influence on improving the organizational citizenship behavior of the employees in the Mold Manufacturing Department of PT. Bumimulia Indah Lestari.

\section{Conclussions}

Based on the analysis and discussion above and the purpose of this study, which is to find out the influence of Work Motivation, Career Development and Work Environment on Organizational Citizenship Behavior on the employees in the Mold Manufacturing Department of PT. Bumimulia Indah Lestari Plant Cikarang, the researchers can conclude from the research results as follows:

a) Appropriate work motivation will affect Organizational Citizenship Behavior as indicated by the object of the study, which was the employees of the Mold Manufacturing Department of PT. Bumimulia Indah Lestari Plant Cikarang. Work motivation had a significant effect on organizational citizenship behavior. This was shown by the Effective Contribution of $6.6 \%$ and the Relative Contribution of $15.2 \%$.

b) Appropriate and fair career development will affect Organizational Citizenship Behavior as indicated by the object of the study, which was the employees of the Mold Manufacturing Department of PT. Bumimulia Indah Lestari Plant Cikarang. Career development had a positive and significant effect on organizational citizenship behavior. This was indicated by the Effective Contribution of $28.7 \%$ and the Relative Contribution of $66.1 \%$.

c) The comfortable work environment will affect Organizational Citizenship Behavior as indicated by the object of the study which was the employees of the Mold Manufacturing Department of PT. Bumimulia Indah Lestari Plant Cikarang. The work environment had a positive and significant effect on organizational citizenship behavior. This was indicated by the Effective Contribution of $8.1 \%$ and the Relative Contribution of $18.7 \%$

d) Organizational citizenship behavior was strongly influenced by work motivation, career development, and the work environment so that companies must have more ability to provide appropriate motivation, fair career development, and a comfortable work environment to improve organizational citizenship behavior of the employees in Mold Manufacturing Department of PT. Bumimulia Indah Lestari's Cikarang Central Branch. This shows that Organizational Citizenship Behavior in the company could be influenced by Work Motivation, Career Development and Work Environment. This was shown by the Effective Contribution with a total of $43.3 \%$ and the Total Relative Contribution of $100 \%$.

Based on the results of the study, limitations in this study can be described as follows: future researches should be able to add employee data that are not yet covered, such as employee salaries, years of service and others. Besides, future researchers should include other variables that have not yet been studied because those variables might influence the results. It is hoped that further researchers can conduct studies using other variables outside the variables that have been studied to obtain better results in improving organizational citizenship behavior. Future studies are also expected to be able to examine variables that strengthen or weaken the relationship between variables in research. 


\section{References}

[1] HestyDwiFebriani, "PengaruhMotivasiKerjaterhadap Organizational Citizenship Behavior", JurnalAplikasiAdministrasi, Vol. 19 No, 2), pp.88-99, Desember 2016.

[2] TryaDewiWidowati, "PengaruhProfesionalisme, BudayaOrganisasi, PengembanganKarier, Dan KomitmenOrganisasiTerhadap Organization Citizenship Behavior Pada Pegawai Kantor KecamatanGondangrejoKabu-Paten Karanganyar", JurnalEkonomi dan Kewirausahaan, Vol. 15 No. 1, pp. : 91 - 99, Maret 2015

[3] Samuel Kailola, "PengaruhKepribadian dan LingkunganKerjaterhadap Organizational Citizenship Behavior dan Kinerja Tenaga Medis (Studi pada RumahSakitSumberHidup dan RumahSakitHative di Kota Ambon)”, Jurnal Manis, Vol. 2 No. 2, pp. 1-20, Agustus 2018

[4] DiahNurhayati, Maria Magdalena Minarsih, dan Heru Sri Wulan, "PengaruhKepuasanKerja, LingkunganKerja Dan LoyalitasKerjaTehadap Organizational Citizenship Behavior (StudiKasus Pada Pt. PerwirabhaktiSentrasejahtera Di Kota Semarang)”. Journal of Management, Vol. 2, No. 2, pp. 1-24), Maret 2016

[5] DevitryRamadianty dan EdylnKhurotulAini. "PengaruhMotivasiterhadap Organizational Citizenship Behavior (OCB) Karyawan Gen-X dan Millenials (Studi Pada Karyawan PT. Temprina Media Grafika Surabaya”, JurnalAdministrasiBisnis (JAB), Vol. 60 No. 2, pp. 1-9, Juli 2018

[6] KadekDiah Candra Dewi dan Gede Riana, "PengaruhMotivasiKerja, KomitmenOrganisasional dan KepuasanKerjaterhadap Organizational Citizenship Behavior PNS pada sekertariat DPRD Kabupaten Bandung", JurnalIlmuManajemen dan Bisnis, Vol. 7 No. 2, pp. 203-214, September 2019, p-ISSN : 0853-9571 e-ISSN : 2477-1767

[7] SiroosGhanbari, Asghar Eskandari, "Organizational Climate, Job Motivation and Organizational Citizenship Behavior”, International Journal of Management Perspective, Vol.1, No.3 pp. 1-14. 2014.

[8] John E. Barbuto Jr. And Joana S. P. Story,"Work Motivation and Organizational Citizenship Behaviors", Journal Of Leadership Studies, Vol. 5, No. 1, pp: 22-34. 2011. DOI:10.1002/jls.20202

[9] Hedge, J.W. and Rineer, J.R. "Improving Career Development Opportunities through Rigorous Career Pathways Research". RTI Press Publication No. OP-0037-1703. Research Triangle Park, NC: RTI Press. https://doi.org/10.3768/rtipress.2017.op.0037.1703 . March 2017.

[10] Diane M. Bergeron, Abbie J. Shipp, Benson Rosen and Stacie A. Furst, "Organizational Citizenship Behavior and Career Outcomes: The Cost of Being a Good Citizen", Journal of Management, Vol. 39 No. 4, pp.: 958-984, May 2013. DOI: 10.1177/0149206311407508

[11] Khaled Mahmoud Al-Shawabkeh," Career Path Development and its Impact on Organizational Citizenship Behavior in Greater Amman Municipality", International Journal of Business and Management; Vol. 12, No. 3, pp.: 79-91. 2017. ISSN 1833-3850 E-ISSN 1833-8119. Published by Canadian Center of Science and Education.

[12] Samuel Kailola, "PengaruhKepribadian dan LingkunganKerjaterhadap Organizational Citizenship Behavior dan Kinerja Tenaga Medis (Studi pada RumahSakitSumberHidup dan RumahSakitHative di Kota Ambon)”, Jurnal Manis, Vol. 2 No. 2, pp. 1-20, Agustus 2018

[13] Suhardi dan Syaifullah, "PengaruhMotivasi, Kompetensi, LingkunganKerja, KompensasiTerhadap Organizational Citizenship Behavior Dan Kinerja KaryawanAsuransi Jiwa Di ProvinsiKepulauan Riau”. JurnalBenefita, Vol. 2 No. 1, pp. : 55-71, Februari 2017

[14] Abda Alif, "PengaruhMotivasiKerja, PengembanganKarir Dan LingkunganKerjaTerhadap Organizational Citizenship Behavior DenganKepuasanKerjaSebagaiVariabel Intervening Pada Perusahaan Terminal LPG”, Jurnal MIX, Vol. VI No. 2, pp. : 291-309, Juni 2015.

[15] Mark C. Bolino, Anthony C. Klotz, William H. Turnley, And Jaron Harvey, "Exploring the dark side of organizational citizenship behavior", Journal of Organizational Behavior, Vol. 34, pp.: 542-559, 7 December 2012. DOI: 10.1002/job.1847.

[16] PurnamieTitiesari, "Peranan Organizational Citizenship Behavior DalamMeningkatkan Kinerja Karyawan”, 2014. Jakarta, Mitra Wacana Media 
[17] Edy Sutrisno, ManajemenSumberDayaManusia, 2019. Jakarta, KencanaPrenadamedia Group.

[18] Muhammad Busro, 2018. Teori-teoriManajemenSumberDayaManusia, Jakarta, KencanaPrenadamedia Group.

[19] $\mathrm{Ni}$ Wayan Sri Indryani dan I KomangArdana, "Peran EmployeEngagmentDalamMediasiPengaruhPengembangankarirTerhadap Organizational Citizenship Behavior pada CS Hotel and SPA Ubud”, E-JurnalManajemen, Vol. 8 No. 9, 2019 :5527-5548 ISSN : 2302-8912

[20] Samuel TiekuGyansah, Hellen KiendeGuantai," Career Development in Organizations: Placing the Organization and the Employee on the Same Pedestal to Enhance Maximum Productivity", European Journal of Business and Management, Vol.10, No.14, pp.: 39-45. www.iiste.org. ISSN 2222-1905 (Paper) ISSN 2222-2839 (Online)

[21] Wendy Hirsh, "Career development in employing organisations: practices and challenges from a UK perspective", This paper is based on an input to the Guidance for Workforce Development Conference, held by CEDEFOP in Thessaloniki, 2007

[22] Ciğdem Kaya and BelginCeylan, "An Empirical Study on the Role of Career Development Programs in Organizations and Organizational Commitment on Job Satisfaction of Employees", American Journal of Business and Management Vol. 3, No. 3, pp. : , 178-191. 2014. DOI: $10.11634 / 216796061403551$

[23] Fadel Shaito," Career Development: An Overview", Research Gate. See discussions, stats, and author profiles for this publication at: https://www.researchgate.net/publication/336812981. Research · October 2019, DOI: 10.13140/RG.2.2.14081.81760

[24] EngaEngetou, "The Impact of Training and Development on Organizational Performance Case study: National Financial Credit Bank Kumba", Thesis Centria University of Applied Sciences Business Management, May 2017

[25] AidahNassazi, "Effects of training on Employee performance. Evidence from Uganda", Business Economics and Tourism, VaasanAmmattikorkeakoulu University of Applied Sciences International Business. 2013.

[26] PandiAfandi," Concept \& Indicator Human Resources Management”. Yogyakarta, Deepublish. 2016.

[27] Cory Searcy, Shane M Dixon, "The Use of Work Environment Performance Indicators in Corporate Social Responsibility Reporting", Journal of Cleaner Production, Vol. 112, · October 2015. DOI: $10.1016 /$ j.jclepro.2015.10.081

[28] Sugiyono, “MetodePenelitianKuantitatif”, Bandung, Alfabeta.2018 